\title{
Penerapan Model Pembelajaran The Learning Cell Dengan Bantuan Media Video Dalam Pembelajaran Akuntansi
}

\author{
Henny Zurika Lubis \\ Putry Ramadhani Sopi Pulungan \\ Fakultas Keguruan dan Ilmu Pendidikan Unversitas Muhammadiyah Sumatera Utara \\ Jl. Mukhtar Basri No. 3 Medan Indonesia \\ Coresponden; hennyzurika@umsu.ac.id
}

\begin{abstract}
Abstrak
Penelitian ini bertujuan untuk mengetahui apakah pembelajaran akuntansi menggunakan model pembelajaran The Learning Cell dengan bantuan Media Video dapat meningkatkan hasil belajar akuntansi siswa pada pokok bahasan jurnal penyesuaian.. Metode penelitian yang digunakan penelitian tindakan kelas (action research) dalam bentuk siklus yang terdiri dari dua siklus dengan empat tahapan yaitu : perencanaan (planning), tindakan (action), pengamatan (observing), dan refleksi (reflecting). Dengan jumlah siswa sebanyak 41 orang, dan instrumen penelitian yang digunakan adalah tes dan observasi. Berdasarkan hasil analisis bahwa adanya peningkatan dari tes awal hanya 10 orang siwa yang tuntas siswa yang tuntas dengan persentase ketuntasan $24.39 \%$ dengan rata-rata kelas $58.90 \%$ menjadi 25 orang siswa dengan persentase ketuntasan $60.98 \%$ dengan rata-rata 78.78 pada siklus I yang terjadi, sehingga pada siklus II adanya peningkatan sebanyak 35 orang siswa dengan persentase ketuntasan $90.24 \%$ dengan rata-rata kelas 85.98. artinya bahwa adanya peningkatan hasil belajar dengan menerapkan model The Learning Cell dengan Bantuan Media Video dalam pembelajaran akuntansi.
\end{abstract}

Kata Kunci : Model the Learning Cell, Media Video, Hasil Belajar Akuntansi.

\begin{abstract}
This research aims to find out if learning accounting using The Learning Cell model with the help of Video Media can improve the results of the study of accounting on the subject of Adjustment Journal. The research method used class action research (action research) in the form of a cycle consisting of two cycles with four stages, namely: planning (planning), action (action), observation (observing), and reflection (reflecting). With the number of students as many as 41 people, and research instrument used is the tests and observation. Based on the results of the analysis that the existence of an increase from the initial test only 10 people complete Shiva students who finished with a percentage of ketuntasan $24.39 \%$ with an average of $58.90 \%$ to class 25 students with percentages ketuntasan $60.98 \%$ with an average 78.78 on cycle I happened, so on cycle II an increase in as many as 35 students with percentages ketuntasan $90.24 \%$ by average grade 85.98. This means that an increase in the results of a study by applying The Learning model of the Cell with the help of Video Media in learning accounting.
\end{abstract}

Keywords: The Learning Cell, Video Media, The Results Of The Study Of Accounting.

\section{PENDAHULUAN}

Pendidikan merupakan kegiatan yang universal dalam kehidupan manusia, dengan pendidikan manusia berusaha mengembangkan potensi yang dimilikinya, mengubah tingkah laku manusia kearah yang lebih baik. 
Liabilities Jurnal Pendidikan Akuntansi

e-ISSN 2620-5866

Volume 1. No.2 Agustus 2018 (156-167)

https://doi.org/10.30596/liabilities.v1i2.2228

Pendidikan juga dapat mencetak masih teoritis dan kurang menerapkan manusia yang handal dan terampil di bidangnya. Tujuan Pendidikan Nasional itu mengandung makna terwujudnya kemampuan bangsa dalam menangkap setiap ajaran, paham atau ideologi yang bertentangan dengan pancasila artinya program dan proses pendidikan semua tingkat dan jelas pendidikan diarahkan untuk mencapai tujuan pendidikan nasional.

Hal ini sesuai dengan hasil kunjungan dan wawancara penulis dengan guru bidang akuntansi, bahwa metode mengajar yang digunakan oleh guru masih menggunakan metode konvensional yaitu ceramah dan tugas, sehingga membuat siswa tidak bersemangat mengikuti pembelajaran di kelas yang berakibat pada suasana belajar yang monoton. Padahal disisi lain mata pelajaran akuntansi merupakan keterampilan yang paling berkaitan dengan keterampilan yang lain, serta harus didukung dengan keterampilan menghitung. Sehingga membuat siswa merasa bosan dan sulit mempelajari akuntansi. Kondisi seperti ini sangat berpengaruh terhadap hasil belajar siswa. Hal ini dapat dilihat dari tes hasil belajar akuntansi yang masih rendah, dari 41 siswa yang hanya mencapai tingkat KKM adalah 10 siswa yang mendapat nilai $\geq 75$, dan selebihnya masih dibawah Standart Ketuntasan Belajar Minimal yaitu $<75$ sebanyak 31 siswa, hal ini karena pembelajaran yang berlangsung disekolah ternyata model pembelajaran yang sudah banyak dikembangkan oleh para ahli. Pembelajaran yang terjadi di kelas $\mathrm{X}$ SMK IRA Medan masih berorientasi pada guru (teacher oriented) yang selama ini dilakukan oleh guru belum sepenuhnya mencapai hasil belajar yang maksimal yang diharapkan untuk seluruh siswa. Keadaan seperti ini menyebabkan siswa belajar secara individu, kurang melibatkan interaksi siswa yang dapat menimbulkan kebosanan siswa terhadap mata pelajaran akuntansi. Siswa hanya mendengarkan penjelasan dari guru tanpa merespon atau menanyakan pelajaran yang tidak dimengerti. Siswa tidak memiliki keberanian dalam memberikan pendapat atau bertanya mengenai materi yang diberikan oleh guru, siswa lebih memilih diam dan lebih senang bertanya dengan teman yang sudah mengerti atau lebih memilih mengobrol dengan teman sebangkunya yang mengakibatkan kelas menjadi tidak kondusif. Siswa juga mengatakan bahwa penjelasan teman biasanya lebih mudah untuk dipahami dan siswa juga bisa mengeluarkan pendapat tanpa rasa takut. Permasalahan tersebut perlu diupayakan pemecahannya, salah satunya melakukan perlakuan yang dapat mengubah suasana pembelajaran yang melibatkan siswa lebih aktif dalam pembelajaran. Pembelajaran aktif adalah suatu rangkaian kegiatan pembelajaran 
Liabilities Jurnal Pendidikan Akuntansi

e-ISSN 2620-5866

Volume 1. No.2 Agustus 2018 (156-167)

https://doi.org/10.30596/liabilities.v1i2.2228

yang mengajak peserta didik untuk belajar secara aktif. Sehingga peserta didik secara aktif menggunakan otak, baik untuk menemukan ide pokok dari materi pelajaran, memecahkan persoalan atau mengaplikasikan apa yang baru mereka pelajari kedalam satu persoalan yang ada dalam kehidupan nyata.

Model pembelajaran The
Learning Cell adalah suatu pembelajaran secara berpasangan, dimana siswa bertanya dan menjawab pertanyaan secara bergantian berdasarkan pada materi bacaan yang sama. Model pembelajaran ini mempermudah siswa dalam memahami dan menemukan masalah yang sulit dengan berdiskusi. The Learning Cell juga mendorong siswa untuk lebih aktif dalam mengemukakan pendapat, melakukan proses kegiatan belajar dengan menekankan cara berpasangan, dan menumbuhkan jiwa kebersamaan pada siswa dalam proses pembelajaran. Dengan penjelasan teman diharapkan materi lebih mudah untuk dipahami, siswa juga bisa mengeluarkan pendapat tanpa rasa takut dan kedua model ini sekiranya dapat membangkitkan minat siswa pada mata pelajaran akuntansi.

Guru sebagai seorang pendidik yang melaksanakan proses pembelajaran harus mampu mengembangkan media dan metode pembelajaran agar meningkatkan efektifitas pembelajaran. Guru juga sebaiknya mampu memanfaatkan teknologi sebagai alat atau media yang menunjang pembelajaran. Teknologi yang harus dimanfaatkan guru merupakan media yang dapat menampilkan berbagai komponen media seperti video, gambar, teks, animasi, dan suara.

Media adalah suatu alat yang dapat digunakan untuk mengemas materi pelajaran agar baik dan menarik. Video adalah salah satu dari media yang dapat dimanfaatkan guru untuk menunjang pembelajaran agar baik dan menarik. Arsyad (2013: 50) berpendapat, "Video dapat menggambarkan suatu objek yang bergerak bersama-sama dengan suara alamiah atau suara yang sesuai. Kemampuan film dan video melukiskan gambar hidup dan suara memberinya daya tarik tersendiri”.

Media pembelajaran video dapat menggambarkan suatu kejadian yang berhubungan dengan materi pelajaran yang menimbulkan kepahaman siswa terhadap materi pelajaran. Maka dari itu, penerapan video sebagai media pembelajaran dianggap mampu meningkatkan hasil capaian belajar siswa. Selain memanfaatkan teknologi untuk media pembelajaran guru juga harus menerapkan metode pembelajaran yang bervariasi. Variasi metode pembelajaran tersebut dimaksudkan untuk meningkatkan partisipasi dan keaktifan siswa dalam proses pembelajaran. Variasi metode pembelajaran juga dimaksudkan untuk meningkatkan pemahaman siswa. Untuk dapat menciptakan suatu 
Liabilities Jurnal Pendidikan Akuntansi

e-ISSN 2620-5866

Volume 1. No.2 Agustus 2018 (156-167)

https://doi.org/10.30596/liabilities.v1i2.2228

pembelajaran akuntansi yang aktif dan memudahkan pemahaman siswa, guru akuntansi hendaknya menerapkan metode pembelajaran yang tepat. Variasi penerapan metode pembelajaran dapat dilakukan dengan pembelajaran yang direkayasa dalam suatu permainan peran tertentu untuk menggambarkan materi pembelajaran.

\section{Model pembelajaran The Learning Cell}

Model pembelajaran The Learning Cell pertama kali dikembangkan oleh Goldschmid dari Swiss Federal Institut of Technology di Lausanne. Menurut Suprijono (2010:122) “The Learning Cell menunjuk pada suatu bentuk pembelajaran aktif dalam berpasangan, dimana siswa bertanya dan menjawab pertanyaan secara bergantian berdasarkan materi yang sama". Model pembelajaran ini mempermudah siswa dalam memahami dan menemukan masalah yang sulit dengan berdiskusi.Learning Cell juga mendorong siswa untuk lebih aktif dalam mengemukakan pendapat dan pertanyaan. Sedangkan menurut Susanti, dkk (2011:53) "Learning Cell adalah salah satu cara dari pembelajaran kelompok, khususnya kelompok kecil". Dalam pembelajaran ini siswa diatur berpasang-pasangan.Salah satunya sebagai tutor, fasilitator/pelatih ataupun konsultan bagi siswa lainnya.Orang yang kedua ini berperan sebagai siswa, peserta latihan ataupun seseorang yang memerlukan bantuan.Model pembelajaran ini mempermudah siswa dalam memahami dan menemukan masalah yang sulit dengan berdiskusi. The Learning Cell merupakan model pembelajaran dimana siswa diberi kesempatan menjawab dan memberikan pertanyaan kepada teman yang disenangi secara bergantian berdasarkan bahan bacaan yang sama. Model pembelajaran ini mendorong timbulnya pertanyaan yang merupakan kunci belajar. Membentuk pasangan belajar yang disenangi diantara siswa merupakan cara efektif untuk mendapatkan pasangan yang bisa dipercaya dalam kegiatan berpasangan dan menempa kemampuan menyimak suatu pendapat.

Istarani (2011:228) mengemukakan langkah-langkah model pembelajaran The Learning Cell adalah sebagai berikut :

1. Sebagai persiapan, siswa diberi tugas membaca suatu bacaan kemudian menulis pertanyaan yang berhubungan dengan masalah pokok yang muncul dari bacaan atau materi terkait lainnya.

2. Pada awal pertemuan, siswa ditunjuk untuk berpasangan dengan mencari kawan yang disenangi. Siswa A memulai dengan membacakan pertanyaan pertama dan dijawab oleh siswa B.

3. Setelah mendapat jawaban dan mungkin telah dilakukan koreksi atau diberi tambahan informasi, 
giliran siswa B mengajukan pertanyaan yang harus dijawab oleh siswa A.

4. Jika siswa A selesai mengajukan satu pertanyaan kemudian dijawab oleh siswa B, ganti B yang bertanya, dan begitu seterusnya.

5. Selama berlangsung tanya jawab, guru bergerak dari pasangan ke pasangan yang lain sambil memberi masukan atau penjelasan dengan bertanya atau menjawab pertanyaan.

Zaini, dkk (dalam Susanti, dkk :2011:54) menyatakan langkahlangkah model pembelajaran kooperatif the learning cell yang sama seperti di atas. Namun, menurut Zaini, dkk model pembelajaran the learning cell ini dapat dimodifikasi dalam bentuk lain. Salah satu bentuk variasi lain dari model ini adalah setiap siswa membaca atau mempersiapkan materi yang berbeda. Dalam contoh seperti ini, siswa A "mengajar" siswa B pokok-pokok dari yang siswa A baca kemudian meminta siswa B untuk bertanya kemudian siswa A dan B berganti peran dan begitu seterusnya.

Dengan penjelasan diatas dapat disimpulkan bahwa model pembelajaran The Learning Cell melibatkan dua orang siswa, salah satu berperan sebagai penanya dan satunya lagi menjawab pertanyaan dan berganti peran dengan materi yang sama ataupun berbeda. Dengan adanya langkah-langkah tersebut diharapkan akan dapat melibatkan siswa secara aktif dalam menyelesaikan tugas atau mencari solusi dari masalah yang telah dibuat sesama siswa sehingga dapat meningkatkan pemahamannya terhadap materi yang dipelajari.

Setiap model pembelajaran memiliki kelebihan dan kelemahan tersendiri, begitu juga dengan model pembelajaran The Learning Cell. Menurut Istarani (2011:228) model pembelajaran The Learning Cell mempunyai beberapa kelebihan dan kelemahan diantaranya:

Kelebihan model pembelajaran The Learning Cell sebagai berikut :

1. Dapat mempermudah persepsi siswa terhadap suatu materi yang diajarkan karena menggunakan bahan bacaan yang sama.

2. Interaksi berjalan sangat baik karena siswa diberikan mencari pasangan sesuai dengan yang ia senangi.

3. Dapat meningkatkan kerjasama diantara siswa karena setiap siswa diberikan kesempatan untuk mengunjungi kelompok atau pasangan yang lain.

4. Dapat menghindari perdebatan yang kurang berarti, karena menggunakan bahan yang sama.

5. Siswa dilatih untuk mengajukan pertanyaan dan menjawab pertanyaan sesamanya dalam kegiatan pembelajaran.

6. Terjadinya pembelajaran yang menyenangkan, tidak membosankan karena berjalan dengan melibatkan siswa secara 
Liabilities Jurnal Pendidikan Akuntansi

e-ISSN 2620-5866

Volume 1. No.2 Agustus 2018 (156-167)

https://doi.org/10.30596/liabilities.v1i2.2228

langsung dalam alur kerja pembelajaran.

7. Pembelajaran akan satu arah, karena ditentukan dari arah materi yang sama.

Kelemahannya model pembelajaran The Learning Cell sebagai berikut :

1. Kurang membuka kesempatan pada siswa untuk mencari bahan lain sebagai bahan perbandingan

2. Guru kurang cukup berperan dalam menyampaikan muatan materi yang diajarkan.

Dari uraian diatas, proses pembelajaran kelompok dengan menggunakan pembelajaran The Learning Cell memiliki kelebihan yang lebih menonjolkan proses pembelajaran dilakukan oleh siswa sendiri baik sesudah pembelajaran atau pada proses pembelajaran itu sendiri, memacu siswa belajar sepanjang waktu dan pembelajaran tidak dilaksanakan hanya pada saat jadwal pembelajaran tetapi sesudah dan sebelum pembelajaran siswa dituntut untuk mendapat informasi tentang materi pelajaran.

Kelemahan dari proses pembelajaran seperti diatas dapat diantisipasi oleh guru dengan beberapa cara sehingga The Learning Cell ini tetap sesuai dengan rencana. Guru dituntut kreatif dalam menumbuhkan kemauan siswa dalam memperolah informasi tentang materi pelajaran terutama sesudah dan sebelum materi diajarkan.

\section{Media Pembelajaran}

Kata media berasal dari bahasa latin dan merupakan betuk jamak dari kata medium yang secara harfiah berarti perantara atau pengantar. Media adalah perantara atau pengantar pesan dari pengirim ke penerima pesan. Kita dapat memahami bahwa media itu alat bantu pembelajaran yang sangat berguna untuk membantu proses pembelajaran peserta didik sehingga tidak terjadi kendala yang muncul dalam proses penyamaian komunikasi pada saat pembelajaran. Dapat juga disimpulkan bahwa media pembelajaran adalah seluruh bahan atau alat yang digunakan untuk fasilitas pembelajaran.

\section{Media Video}

Video, sebagai media audio-visual yang menampilkan gerak, semakin lama semakin popular dalam masyarakat kita.Pesan yang disajikan bisa bersifat fakta (kejadian/peristiwa penting, berita) maupun fiktif, bisa bersifat informative, edukatif maupun instruksional. Sebagian besar tugas film dapat digantikan oleh video. Tapi tidak berarti bahwa video akan menggantikan kedudukan film. Masing-masing mempunyai kelebihan dan keterbatasan sendiri. Kelebihan video antara lain :
a. Dapat menarik perhatian untuk periode - periode yang singkat dari rangsangan luar lainnya.
b. Dengan alat perekam pita video
besar penonton dapat 
memperoleh informasi dari ahli ahli/ spesialis.

c. Demonstrasi yang sulit bisa dan direkam sebelumnya, sehingga pada waktu mengajar guru bisa memusatkan penyajian pada penyajiannya.

d. Menghemat waktu dan rekaman dapat diputar berulang - ulang.

e. Kamera TV bisa mengamati lebih dekat objek yang sedang bergerak atau objek yang berbahaya seperti harimau.

f. Keras lemah suara yang ada bisa diatur dan disesuaikan bila akan disisipi komentar yang akan didengar.

g. Gambar proyeksi biasa di "beku"-kan untuk diamati dengan seksama. Guru bisa mengatur dimana dia akan menghentikan gerakan gambar tersebut. Control sepenuhnya ditangan guru, dan

h. Ruangan tak perlu digelapkan waktu menyajikannya.

Sedangkan kelemahan dari media video adalah :

a. Sifat komunikasinya bersifat satu arah dan harus diimbangi dengan pencarian bentuk umpan balik yang lain.

b. Kurang mampu menampilkan detail dari objek yang disajikan secara sempurna, dan

c. Memerlukan peralatan yang mahal dan kompleks.

Selanjutnya, desain pembelajaran diimplementasikan dalam kegiatan belajar mengajar, yang dalam hal ini pelaksanaannya dilihat melalui siklus tindakan kelas dimana dalam satu siklus terdiri dari beberapa tahap; perencanaan, pelaksanaan, tindakan, pengamatan,dan refleksi. Jika hasil belajar siswa lebih baik dari pada siklus sebelumnya bermakna bahwa pembelajaran The Learning Cell berlangsung dengan baik. Ini terjadi karena dalam pembelajaran siswa dilatih unuk belajar bekerja sama dengan siswa lainnya, sehingga antara siswa yang satu dengan yang lainnya saling mengisi untuk mencapai tujuan bersama. Selain itu dengan pembelajaran ini akan memberikan kesan belajar sehingga pembelajaran tersebut benar-benar dirasakan oleh siswa dibandingkan dengan pembelajaran yang dilakukan secara konvensional.

Dengan menggunakan model pembelajaran The Learning Cell dengan menggunakan bantuan media video pada pembelajaran akuntansi yang diharapkan dapat meningkatkan penalaran terhadap siswa. Pemahaman konsep secara logika akan mengurangi kesalahan pengerjaan yang dilakukan. Sehingga siswa dapat menggunakan daya nalarnya untuk memecahkan masalah yang ada. Dari kerangka konseptual yang diuraikan, maka peniliti akan memberikan gambaran secara skematis yang dapat dijelaskan sebagai berikut : 
Liabilities Jurnal Pendidikan Akuntansi

e-ISSN 2620-5866

Volume 1. No.2 Agustus 2018 (156-167)

https://doi.org/10.30596/liabilities.v1i2.2228

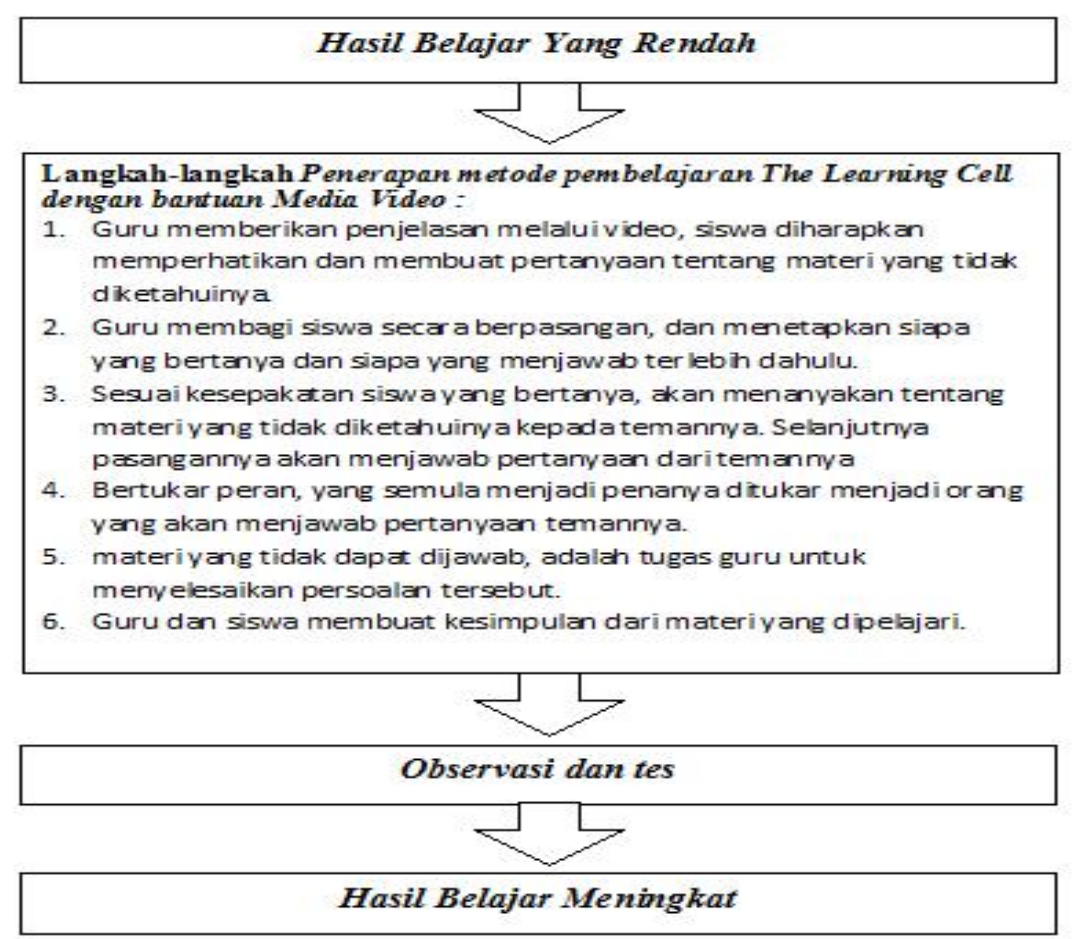

\section{METODE PENELITIAN}

Penelitian ini merupakan Penelitian Tindakan Kelas. Arikunto (2010: 131) mengemukakan secara garis besar terdapat empat tahapan yang dilalui dalam melaksanakan penelitian tindakan kelas yaitu: (1)

perencanaan (planning)

pelaksanaan (acting) (3) pengamatan (observasing) (4) refleksi (reflecting). Adapun model dan penjelasan masing-masing tahap sebagai berikut:

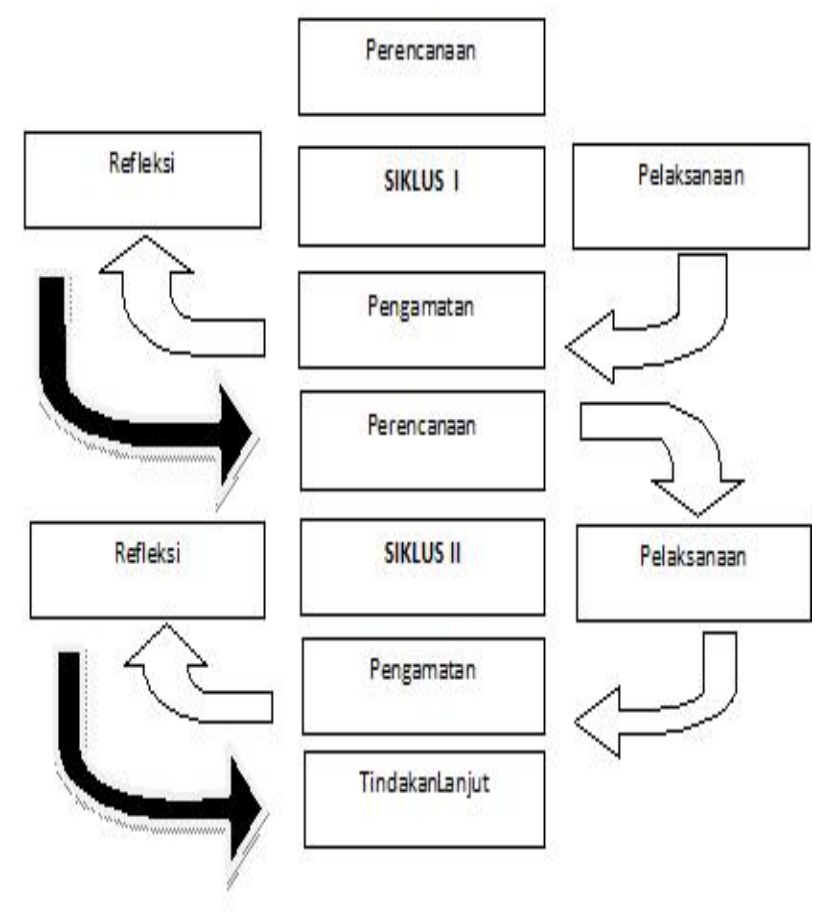

Gambar.

Model Penelitian Tindakan Kelas 
Liabilities Jurnal Pendidikan Akuntansi

e-ISSN 2620-5866

Volume 1. No.2 Agustus 2018 (156-167)

https://doi.org/10.30596/liabilities.v1i2.2228

\section{Teknik Analisis}

Untuk mendeskrifsikan data dari variabel penelitian digunakan statistik deskriptif, yaitu mendeskrifsikan, mencatat dan menganalisa data. Setelah data didapatkan, kemudian diolah dengan teknik analisa data sebagai berikut :

1. Menghitung Rata-rata Skor $\mathbf{x}=\frac{\Sigma f}{\Sigma f} \ldots \ldots \ldots . .($ Sudjana, 2005: 67)

dimana :

$f i=$ Banyak soal

$x i=$ Nilai masing-masing siswa

2. Menghitung tingkat ketuntasan belajar

Untuk menentukan daya serap siswa secara individual digunakan rumus sebagai berikut:

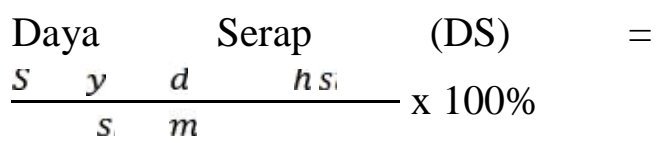

(Sudjana,2005: 112)

Kriteria :

$0 \% \leq \mathrm{TK} \leq 70 \%=$ tidak tuntas

$70 \% \leq \mathrm{TK} \leq 100 \%=$ tuntas

Selanjutnya dapat diketahui ketuntasan belajar siswa secara klasikal dengan rumus berikut :

$\mathrm{D}=\frac{X}{N} \mathrm{X} 100 \% \quad($ Sudjana,2005: 115)

Dimana :
$\mathrm{D}=$ Prestasi kelas yang telah dicapai daya serapnya $\geq 70 \%$

$\mathrm{X}=$ Jumlah siswa yang telah mencapai daya serap $\geq 70 \%$

$\mathrm{N}=$ Jumlah siswa

Berdasarkan kriteria ketuntasan belajar, jika kelompok secara klasikal tersebut telah mencapai $70 \%$ maka ketuntasan secara klasikal telah terpenuhi.

\section{HASIL DAN PEMBAHASAN}

Dalam simulasi pada awal pembelajaran, guru bidang studi akuntansi mengajar seperti biasanya, dimana guru hanya menggunakan metode konvensional dan tanya jawab sederhana. Dalam menerangkan materi pembelajaran, guru kurang memperhatikan tingkah laku siswa, sehingga siswa merasa kurang atau tidak diperhatikan tingkah laku siswa, sehingga siswa merasa kurang atau tidak diperhatikan oleh guru saat kegiatan helajar mengajar berlangsung. Hal ini dapat mengakibatkan siswa kurang bersemangat dalam belajar, merasa bahwa belajar akuntansi membosankan dan ada juga siswa yang dengan sengaja ribut di dalam kelas pada saat kegiatan belajar mengajar berlangsung.

Dalam kegiatan dalam belajar mengajar dengan menggunakan metode konvensional ini. Siswa kurang aktif dalam kegiatan belajar mengajar dan siswa jarang bertanya dan mengemukakan pendapat. Proses belajar mengajar terjadi satu arah 
Liabilities Jurnal Pendidikan Akuntansi

e-ISSN 2620-5866

Volume 1. No.2 Agustus 2018 (156-167)

https://doi.org/10.30596/liabilities.v1i2.2228

(hanya berpusat pada guru). Dengan demikian hasil belajar siswa masih tergolong rendah. Hal ini dikarenakan banyak siswa yang tingkat penguasaan tentang materi yang diajarkan masih rendah sehingga hasil belajar yang diperoleh tidak mencapai kriteria ketuntasan minimal.

Oleh karena itu peneliti merencanakan untuk materi Jurnal Penyesuaian menerapkan model pembelajaran The Learning Cell dengan Bantuan Media Video saat kegiatan berlangsung. Selama kegiatan belajar mengajar berlangsung, peneliti mengobservasi aktivitas siswa dengan menilai aktivitas siswa selama proses pembelajaran The Learning Cell dengan Bantuan Media Video mengalami peningkatan yang snagat signifikan sebelum diterapkan model pembelajaran The Learning Cell dengan Bantuan Media Video.

Pada siklus I, peneliti mulai menerapkan model The Learning Cell dengan Bantuan Media Video dengan mengacu pada perencanaan pembelajaran yang telah disusun dan disesuaikan sebelumnya. Pada siklus I hasil yang diperoleh adalah 25 siswa yang mencapai kriteria tuntas dengan persentase $60.98 \%$ dan nilai rata-rata kelas 78.78. Berdasarkan hasil dari siklus I peneliti menyimpulkan bahwa masih terdapat kendala dalam kegiatan belajar mengajar hal ini disebabkan karena siswa belum terbiasa dengan model pembelajaran
The Learning Cell dengan Bantuan Media Video yang digunakan peneliti. Peningkatan hasil belajar pada pokok bahasan Jurnal Penyesuaian terlihat pada siklus II diperoleh ratarata kelas 85.98, dengan jumlah yang tuntas sebanyak 37 siswa dan persentase ketuntasan 90.24\%. Berikut ini adalah tabel ketuntasan dalam setiap tindakan hasil belajar sebagai berikut:

Tabel 4.9

Hasil Belajar Siswa Kelas X

Siklus I dan II

\begin{tabular}{|l|l|l|l|l|}
\hline No & Tindakan & $\begin{array}{l}\text { Jumlah } \\
\text { siswa }\end{array}$ & Keterangan & Persentase \\
\hline 1 & Siklus I & $\begin{array}{l}25 \\
16\end{array}$ & $\begin{array}{l}\text { Tuntas } \\
\text { Tidak } \\
\text { Tuntas }\end{array}$ & $\begin{array}{l}60.98 \% \\
39.02 \%\end{array}$ \\
\hline 2 & Siklus II & 37 & $\begin{array}{l}\text { Tuntas } \\
\text { Tidak }\end{array}$ & $\begin{array}{l}90.24 \% \\
\text { Tuntas }\end{array}$ \\
& & 4 & $9.76 \%$ \\
\hline
\end{tabular}

Adapun grafik dari tabel keseluruhan hasil ketuntasan belajar siswa sebagai berikut :

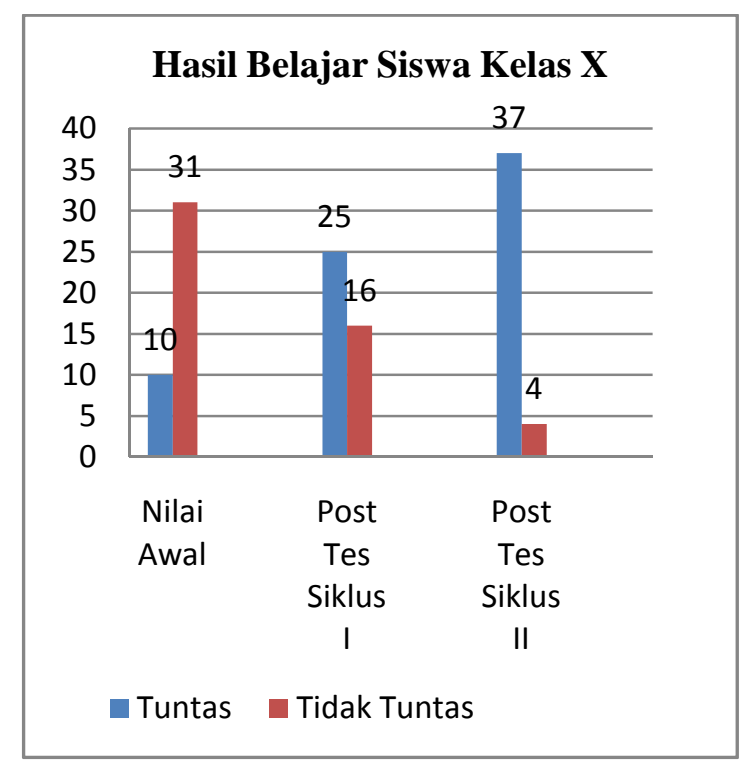

Grafik 
Liabilities Jurnal Pendidikan Akuntansi

e-ISSN 2620-5866

Volume 1. No.2 Agustus 2018 (156-167)

https://doi.org/10.30596/liabilities.v1i2.2228

\section{Hasil Belajar Akuntasi Siswa per siklus}

Dari grafik diatas dapat diketahui bahwa adanya peningkatan dari tes awal hanya 10 orang siswa yang mencapai ketuntas dengan persentase ketuntasan $24.39 \%$ dengan rata-rata kelas $58.90 \%$ menjadi 25 orang siswa dengan persentase ketuntasan $60.98 \%$ dengan rata-rata 78.78 dari siklus I yang terjadi, sehingga pada siklus II meningkat sebanyak 35 orang siswa dengan persentase ketuntasan $90.24 \%$ dengan rata-rata kelas 85.98. Sehingga ada peningkatan hasil belajar dengan menerapkan model The Learning Cell dengan Bantuan Media Video.

\section{KESIMPULAN DAN SARAN}

\section{Kesimpulan}

1. Penerapan Metode Pembelajaran The Learning Cell Dengan Bantuan Media Video dapat Meningkatkan Hasil Belajar Akuntansi siswa

2. Hasil belajar siswa setelah diterapkan Metode Pembelajaran The Learning Cell Dengan Bantuan Media Video dapat Meningkat. Pada siklus I diperoleh dengan persentase siswa sebesar $60,98 \%$, sedangkan pada siklus II diperoleh nilai dengan persentase $90.24 \%$. Hal ini mengalami peningkatan sebesar $29.26 \%$ persentase siswa yang telah mencapai Standar Ketuntasan Maksimal $\geq 75$.

\section{Saran}

1. Sebaiknya dalam pembelajaran akuntansi guru dapat menggunakan Metode Pembelajaran The Learning Cell Dengan Bantuan Media Video sebagai salah satu alternatif penggunaan metode dalam pengajaran akuntansi agar pembelajaran lebih menarik dan bervariasi.

2. Bagi sekolah dapat mengupayakan berbagai sarana dan prasarana untuk mendukung model pembelajaran untuk memperbaiki kualitas pembelajaran bagi siswa dikelas.

\section{DAFTAR PUSTAKA}

Arikonto,Suharsimi. 2008. Prosedur Penelitian. Jakarta: Rineka Cipta. Asrar,dkk. 2013. Media Pembelajaran. Medan : Perdana Publishing.

Dimyati, Mudjiono. 2006. Belajar dan Pembelajaran. Jakarta: PT. Ahdi Mahastya.

Hamalik. 2010. Proses Belajar Mengajar dalam Syam. 2013. Pengertian Hasil Belajar. Diakses 25 Februari 2015.

http://rahmadhanipohan.blogspot.co.i d/ 2012. Interpretasi Nilai Evaluasi Menilai PAN dan PAP. Diakses pada tanggal 12 Desember 2015 
Liabilities Jurnal Pendidikan Akuntansi

e-ISSN 2620-5866

Volume 1. No.2 Agustus 2018 (156-167)

https://doi.org/10.30596/liabilities.v1i2.2228

Purwanto. 2010. Evaluasi Hasil

Menggunakan Model

Belajar. Yogyakarta: Pustaka

Pembelajaran Kooperatif Tipe The

Belajar.

Rasyidin, dkk. 2012.Teori Belajar

dan Pembelajaran. Medan:

Perdana Publishing.

Rusman. 2012. Model-model

Pembelajaran Mengembangkan

Profesionalisme Guru. Jakarta :

Raja Grafindo Persada.

Sanjaya, Wina. 2006. Strategi

Pembelajaran Berorientasi

Standar Proses Pendidikan.

Jakarta : Kencana Perdana Media

Group.

Slameto. 2010. Belajar Dan Faktor-

Faktor Yang Mempengaruhinya.

Jakarta: Rineka Cipta.

Sucipto, dkk. 2009. Akuntansi 1. Jakarta : Yudhistira.

Sugiyono. 2013. Metode Penelitian Pendidikan (Pendekatan

Kuantitatif, kualitatif, dan $R \& D)$.

Cv. Alfabeta. Bandung.

Suprijono, Agus. 2010. Cooperative

Learning Teori dan Aplikasi

Paikem. Yogyakarta: Pustaka

Pelajar

Susanti, dkk. 2011. Studi

Perbandingan Hasil Belajar

Matematika Siswa Dengan

Learning Cell Dan Tipe Artikulasi

Di Kelas VII SMPN 7 MA. Jambi.

Journal Edumatica, volume 01, nomor 02. ISSN 2088-2157

Tersedia di : http://online-

journal.unja.ac.id/index.php/eduma tica/article/view/180 [diakses 0502-2015]

Suyanto, dkk. 2013. Menjadi Guru

Profesional Strategi Meningkatkan

Kualifikasi dan Kualitas Guru di

Era Global. Jakarta : Erlangga Group

Syafri, sofyan. 2011. Teori Akuntansi. Jakarta: Rajagrafindo Persada.

Syam. 2013. Pengertian Hasil Belajar. Tersedia : http://syam.blogspot.com /2013/04/hasil-belajar. Diakses 25 Februari 2015

Yetti, Novi. 2014. Penerapan Model Pembelajaran Learning Cell Dengan Strategi Pembelajaran Active Knowledge Sharing Untuk Meningkatkan Aktivitas Dan Hasil Belajar Siswa Kelas X AK SMK Negeri 7 Medan Tahun Ajaran 2013/2014. Medan : Skripsi Unimed. 